REVISTA DE DERECHO UNED, NÚM. 23, 2018

\title{
ASPECTOS MÁS RELEVANTES DE LAS INSTRUCCIONES Y PREVENCIONES A LOS COMISIONADOS ENVIADOS A ULTRAMAR
} EN 1822

\author{
MOST RELEVANT ASPECTS OF THE INSTRUCTIONS \\ AND PREVENTIONS TO COMMISSIONERS SENT ULTRAMAR \\ IN 1822
}

Miguel Ángel Castro Vaquero

Programa de Doctorado en Derecho y Ciencias Sociales. UNED

Resumen: El año 1822 supone el cambio de rumbo en la política ultramarina, basada en la negociación y el entendimiento como última esperanza de salvaguardar la integridad del Orbe Hispánico. Este cambio se encabezó desde las Cortes españolas que, conscientes del final inevitable que la política de enfrentamiento con los disidentes iba a producir, encomendaron al Ejecutivo enviar a América comisionados para oír y recibir propuestas de los Gobiernos disidentes de Ultramar, siempre que fuera acorde con la dignidad y el decoro de la Nación, para conseguir la tan ansiada pacificación de Ultramar.

Esta encomienda tan trascendental y difícil se vio truncada por múltiples factores, pero no por ello se puede perder de vista el enorme valor histórico y jurídico que implicaba englobar en pie de igualdad a una gran parte del mundo bajo dominio europeo, en este caso español, a la senda constitucional.

Palabras clave: Comisionados, América, Cortes, Constitución, Pacificación.

Abstract: The year 1822 represents a change of direction in the ultramarine policy, based on the negotiation and the understand-

(C) UNED. Revista de Derecho UNED, núm. 23, 2018 
ing as last hope to safeguard the integrity of the Hispanic Orb. This change was led by the Spanish Parlament, aware of the inevitable ending that the policy of confrontation with dissidents was going to produce, entrusted the Executive Government to send commissioners to America to hear and receive proposals from Ultramarine dissident Governments, as long as it was in accordance with the dignity and the decorum of the Spanish Nation, to achieve for the the longed awaited pacification with Ultramar.

This decisive and difficult assignment was truncated by multiple factors, but that does not mean that we should lose sight of the enormous historical and legal value that included similar condition to most of the world under European control, in this case Spanish control, to the constitutional path.

Keywords: Commissioners, America, Parlament, Constitution, Pacification.

Recepción original: 02/07/2018

Aceptación original: 08/09/2018

Sumario: I. Introducción.-II. España ante el conflicto americano. II.1. Punto de partida de la posición española. II.2. Posición peninsular.-III. Instrucciones y prevenciones. III.1. Contexto de las instrucciones. III.2. Vinculación jurídica entre los comisionados y el Ejecutivo. III.3. Principales contenidos. III.3.1. Posiciones prudentes frente a intransigentes. III.3.2. Referencia a la Constitución española y a las Cortes. III.3.3. Unidad frente a separación.IV. Conclusiones.-V. Fuentes y bibliografía.

\section{INTRODUCCIÓN}

El trienio liberal (1820-1823) constituye un periodo apasionante en lo que a cambios legislativos y jurídicos en la relación con las antiguas colonias españolas en América se refiere ${ }^{1}$. Las principales instrucciones y prevenciones dadas a los comisionados regios, enviados a finales de 1822 para llevar a cabo la pacificación a través de la negociación con los gobiernos disidentes establecidos en las provincias

${ }^{1}$ Para un análisis del marco político del Trienio, véase ARTOLA, M., «la España de Fernando VII», en Historia General de España, dirigida por José María Jóver Zamora, Madrid, Espasa-Calpe, 1988, págs. 136 y ss. Para una relación bibliográfica sobre esta época puede consultarse GIL NOVALES, A., El Trienio Liberal, Madrid, Siglo XXI, 1980. A este periodo el autor ha dedicado varios trabajos, entre los que destaca su libro, Las Sociedades Patrióticas, Madrid, Tecnos, 1975. 
de Ultramar y que aspiraban a obtener la independencia de derecho partiendo de la existencia de hecho que ya disfrutaban, será el centro de nuestra atención.

No hay que olvidar que los vaivenes políticos durante el trienio liberal en la Península fueron constantes a pesar del corto periodo histórico que abarcó (no llegó a cuatro años) ${ }^{2}$, y esos cambios afectaron, en gran medida, a la resolución del conflicto con Ultramar ${ }^{3}$.

El retorno del sistema liberal y constitucional, a partir del pronunciamiento del coronel Riego en Cabezas de San Juan el 1 de enero de $1820^{4}$, transformó la forma de afrontar el problema independentista ante la falta de resultados contundentes a pesar del esfuerzo bélico y económico llevado a cabo por España ${ }^{5}$. Dentro del período que abarcó el trienio liberal, el año 1822, coincidiendo con el protagonismo político de los exaltados ${ }^{6}$, permitió un cambio de rumbo respecto al problema americano ${ }^{7}$.

Los debates en las Cortes fueron in crescendo y los planteamientos de los diputados iban desde el pleno reconocimiento de la independencia a la intransigencia absoluta ${ }^{8}$. Al final, ganó peso la

${ }^{2}$ En este punto, remitimos al lector al estudio de PEÑA GONZÁLEZ, J., Historia política del constitucionalismo español, Dykinson, Madrid, 2006.

3 Para más información, véase el trabajo de VARELA SUANZES-CARPEGNA, J., «La Monarquía imposible: la Constitución de Cádiz durante el Trienio», en Anuario de Historia del Derecho Español, t. LXVI 1996, págs. 653-687.

${ }^{4}$ En realidad tardó un par de meses (hasta marzo) en triunfar el alzamiento. Durante esos meses hubo otros alzamientos (La Coruña, Ferrol, Vigo, Zaragoza, Barcelona, Pamplona y otros lugares). Cfr. FRIEDE, J., «España y la Independencia», en Boletín Cultural y Bibliográfico, Vol. 9, n. ${ }^{\circ}$ 5, 1966, pág. 849

5 Como destaca SÁNCHEZ ANDRÉS, A. «La búsqueda de un nuevo modelo de relaciones con los territorios de Ultramar durante el Trienio Liberal (1820-1823)», en Revista de Indias, 1997, vol. LVI, núm. 210, págs. 451-474, en relación a LYNCH, J., Las revoluciones hispanoamericanas, 1808-1826, Barcelona, Ariel, 1983, págs. 1547, «... La política represiva practicada entre 1814 y 1829 , pese a los efímeros éxitos militares conseguidos, había supuesto la desaparición de cualquier solución a la crisis colonial que no pasara por el reconocimiento de la independencia de la mayoría de dichos territorios...»

${ }^{6}$ VARELA SUANZES-CARPEGNA, J., op. cit. págs. 653-687.

7 Se lee dictamen de la Comisión de Ultramar sobre las medidas que deberían tomarse con respecto a aquellas provincias, DSC 24 enero 1822, págs. 1975-1976. Legislatura Extraordinaria 1821-1822

8 JENSEN, S.I. «El problema americano en el Trienio Liberal. Análisis de las Políticas de Ultramar de las Cortes Españolas (1820-1823)», en Trienio, n. ${ }^{\circ} 28$, nov. de 1996, pág. 78 «...paralelamente a que determinadas diputados se empeñaban por conservar como única fórmula posible de entendimiento, el reconocimiento de la unidad política por parte de los americanos, y seguían confiando en el poder convocante del texto constitucional; lentamente se fueron multiplicando las propuestas y proyectos que analizaban otras vías...».

(C) UNED. Revista de Derecho UNED, núm. 23, 2018 
intermedia, esto es, la búsqueda del entendimiento a partir de la negociación en pie de igualdad, permitiendo muchas concesiones pero sin atentar contra los principios de fraternidad, el decoro y dignidad de la Nación ${ }^{9}$, ni menoscabar la integridad del territorio.

Para llevar a cabo esta tarea, de verdadera pedagogía, de convencer sobre los beneficios que el nuevo sistema constitucional podía llevar a América ${ }^{10}$, al igual que ya lo estaba haciendo en la Península, las Cortes encomendaron al Ejecutivo la labor de nombrar a unos comisionados que, por su talento y conocimiento de la situación en América ${ }^{11}$, fueran para oír y recibir proposiciones, con el objetivo de lograr la paz y reconciliación entre lo que para muchos diputados no eran más que disensiones de familia ${ }^{12}$. Gran parte de los debates se centraron en si el envío de estos comisionados implicaba o no el reconocimiento de la independencia, rechazándose por muchos diputados, así como por el Ejecutivo y el propio Monarca.

De esta forma, el Rey, como cabeza del Ejecutivo, nombró a 12 comisionados que debían llevar a cabo la tarea posiblemente más ardua y difícil que unas Cortes españolas hayan encomendado a nadie, la pacificación del Orbe Hispánico bajo los valores de igualdad, unidad y libertad que supuestamente garantizaba la Constitución de 1812.

Por parte del Ejecutivo español, bajo la supervisión del Rey, se elaboraron una serie de instrucciones y prevenciones a las que los comisionados debían ceñirse para lograr el éxito de esta difícil y peligrosa tarea, si bien disfrutaron de un cierto margen de actuación, basado en la prudencia y circunspección, por la que fueron nombrados en un contexto nada propicio para el buen resultado que se esperaba.

9 Art. 9 Instrucciones, Archivo General de Indias (en lo sucesivo AGI). Sevilla. Indiferente General (en lo sucesivo IG). Legajo 1570.

10 Sobre ello, cfr. CHUST, M., «La notoria trascendencia del constitucionalismo doceañista en las Américas», Corts: Anuario de derecho parlamentario, n. ${ }^{\circ} 26,2012$, págs. 47-58.

${ }^{11}$ Para la elección personal de los comisionados se pidió informe reservado a varios consejeros de Estado y tenientes generales así como al Ministro del Tribunal Supremo de Justicia. Cfr. FRIEDE, J., «España ante la independencia», en Boletín Cultural y Bibliográfico, Vol. 10, n. ${ }^{\circ}$ 11, 1967, pág. 33, en relación al informe reservado dirigido a Fernando VII confeccionado por los Secretarios de Cortes sobre lo actuado en estas y en el Consejo de Estado de junio de 1821 a octubre de 1822.

12 Diario de Sesiones de Cortes (en lo sucesivo DSC) 12 de febrero de 1822, ver intervención del diputado Marcial López, pág. 2277, n. ${ }^{\circ}$ 140, «la guerra se hace con las naciones extrañas; y aquellas no lo son. Aquello es una verdadera rebelión...». 
Podemos afirmar que se trató del último movimiento de acercamiento en una partida que estaba condenada al fracaso por intereses tanto foráneos como meramente comerciales por disolver el Universo Hispánico que dominaba el mundo de los últimos tres siglos.

\section{ESPAÑA ANTE EL CONFLICTO AMERICANO}

Conocer la posición española en el conflicto ultramarino es conditio sine qua non para comprender el contexto en el que se gestaron las instrucciones y prevenciones dadas a los comisionados para tratar de conseguir la tan ansiada pacificación.

\section{II.1. Punto de partida de la posición española}

España basaba su posición en esta negociación bajo dos premisas:

1. La unión hace la fuerza puesto que los americanos sin su vinculación a España están desvalidos. América bajo un solo Gobierno «continuará perfeccionado su civilización y aumentado indefinidamente su prosperidad y riqueza». Divididos, serían expuestos «al influjo inmediato de los Gobiernos extranjeros, poderosos y comerciantes»; serán «juguete de ambición»; considerándolos «únicamente como mercados para dar salida a sus producciones ${ }^{13}$.

2. Los beneficios que otorga la Constitución de 1812 para América, garantiza su «independencia» dentro de la integridad ${ }^{14}$. Las autoridades peninsulares tienen una fe ciega en las bondades de la Constitución y en que los americanos las abrazarán sin miramientos. Desde la perspectiva liberal peninsular, creer lo contrario no tenía sentido tras las penurias y persecuciones que habían sufrido en España durante el sexenio absolutista, y que en muchas ocasiones llevó a muchos diputados al presidio, al exilio o al cadalso.

Frente a esta situación, en América nunca se llegó a vivir bajo los bondadosos principios constitucionales debido al conflicto que

13 Art. 19 Instrucciones, AGI. Sevilla. IG. Legajo 1570.

14 Ibid., "... Que el sistema de integridad, reuniendo en un solo centro el poder de todos los españoles de ambos hemisferios, da a la independencia de todos una garantía invencible que se pierde con la separación...». 
desde 1810 atravesaba el continente ${ }^{15}$. Es por ello que todas estas promesas «caían en saco roto» en Ultramar, con una continua inestabilidad política y militar ${ }^{16}$.

En definitiva, la vigencia de la Constitución de 1812 nunca fue fácil, ya que no era querida ni desde fuera de la Península por los americanos, ni desde dentro; primero, por parte de la facción absolutista - que durante el trienio intentó llegar por la fuerza al poder varias veces-, y segundo, por el propio Rey, que siempre que pudo boicoteó la labor de las Cortes gracias al veto suspensivo que constitucionalmente se le otorgaba ${ }^{17}$.

¿Justificar la paz basada en la Constitución fue un error?

Si bien no se puede achacar la pérdida de las provincias ultramarinas a la existencia de la Constitución de Cádiz, sí puede afirmarse que la creencia por parte de las autoridades peninsulares de que con la vigencia de la Constitución dejarían de tener causa o fundamento el malestar de los americanos fue un error de enormes dimensiones ${ }^{18}$.

Ni los hombres que debían aplicarlo, ni la madurez del pueblo que debía recibirla como propia, estaban convencidos de un régimen que a todas luces estaba condenado al fracaso. Como destaca Sánchez Andrés, "paralelamente la Revolución de 1820 precipitó el proceso emancipador americano al enajenar el apoyo a la metrópoli de las oligarquías coloniales más conservadoras, que, desde 1810, habían construido el principal y casi único soporte de la Corona en América ${ }^{19}$.

Los absolutistas no creían en dicho régimen ya que limitaba las competencias del Monarca y los liberales querían reformar la Constitución tras la "templanza» que muchos diputados tuvieron tras sus exilios europeos durante el sexenio absolutista ${ }^{20}$. La Constitución

15 Art. 2 Prevenciones Reservadas a los Comisionados, AGI. Sevilla. IG. Legajo 1570, «... Aunque en lo general la parte insurreccionada de América no ha gozado de los bienes que son consiguientes al sistema constitucional...».

${ }^{16}$ El diputado Ramírez exponía en las Cortes el 25 de junio de 1821 que la necesaria delegación del poder de las Cortes en las autoridades ejecutivas de la colonia hacía imposible la aplicación del marco constitucional (DSC 25 junio 1821, núm. 118).

17 VARELA SUANZES-CARPEGNA, J., op. cit. pág. 656.

18 En este contexto, se recomienda la lectura del trabajo de PASCUAL, P., La unión con España, exigencias de los diputados americanos en las Cortes de Cádiz, Comunidad de Madrid, 2001.

${ }^{19}$ Cfr. SÁNCHEZ ANDRÉS, A., op. cit., págs. 451-474.

${ }^{20}$ Bentham influyó en tres destacados liberales asturianos: el Conde de Toreno, A. Argüelles, Canga Argüelles, con los que mantuvo una relación epistolar. Cfr. VARELA SUANZES-CARPEGNA, J.. op. cit., pág. 669. 
de 1812 ya no era suficiente para calmar la situación histórico-política del trienio liberal.

En el trienio, a diferencia de cuando se gestó la Constitución en Cádiz en 1810, la Península no estaba inmersa en una guerra de invasión y, por tanto, no estaba amenazada la Nación. Además, el Rey se encontraba presente, mientras que antes estaba preso por Napoleón, que no era proclive a sus directrices. La Constitución restó muchos de los poderes del Rey, pero mantenía importantes prerrogativas como el veto suspensivo que podían paralizar cualquier tipo de iniciativa legislativa ${ }^{21}$.

De esta forma el conflicto entre los poderes del Estado estaba asegurado. Muchos liberales peninsulares de la facción moderada, así como muchos liberales de las principales potencias europeas querían la reforma constitucional para «templar» la Constitución de 1812 y asemejarla más al constitucionalismo británico, acercándose a los tintes doctrinarios que primaban en la Europa de la época.

Por el contrario, los liberales peninsulares exaltados, que en las décadas siguientes se les llamará progresistas, querían que el Legislativo dominara al Ejecutivo para evitar cualquier tipo de reminiscencia regia que pueda impedir la labor del órgano más importante, en su opinión, de la Nación española, las Cortes.

En medio de este clima, el conflicto americano no podía caer en peor momento, y ante este problema, enquistado desde hacía años, se intentó llegar a una solución más o menos acertada como fue la negociación con los insurgentes americanos que disponían de gobiernos paralelos disidentes que ejercían sus funciones en los territorios bajo su dominio.

Hay que tener en cuenta que el envío de comisionados, que surgió del mandato de las Cortes, tuvo lugar tras los decisivos debates de comienzos de 1822, momento en el que los exaltados tienen mayoría en las Cortes.

En principio, se les autorizó para oír y recibir toda clase de proposiciones, aunque claro está, con los límites establecidos por el Decreto de 13 de febrero de 1822. De hecho en las instrucciones se hace referencia varias veces a esos límites ${ }^{22}$. Se destaca en diversas

${ }^{21}$ Cfr. TORRES DEL MORAL, A., "1812: La apuesta constitucional de Cádiz», Servicio de publicaciones Universidad de Cádiz, Cádiz, 2014, págs. 253-255.

22 Arts. 13 y 15 Instrucciones (se refiere al art. 1 del Decreto 13 febrero 1822); Art. 1 Instrucción Adicional (se refiere al art. 1 del Decreto 13 de febrero 1822); Art. 8 Instrucción Adicional (se refiere al art. 4 del Decreto 13 de febrero 1822).

(c) UNED. Revista de Derecho UNED, núm. 23, 2018 
ocasiones el art. 4 del Decreto de 13 de febrero, en el que se dice expresamente que España no renuncia a sus derechos sobre América. Este límite fundamental justifica los esfuerzos ímprobos que debían llevarse a cabo. Si se llegara a plantear la separación, los comisionados debían hacer ver que no había mayor independencia que la que otorgaba la Constitución de Cádiz ${ }^{23}$.

El lenguaje dado en las instrucciones evidencia la posición de España en el conflicto. Y es que, los términos "prudencia», "circunspección», "discreción», "confianza», se repiten en múltiples ocasiones. De hecho, para la selección de los comisionados, estos términos han sido claves para que los elegidos fueran los más adecuados. Partiendo de la base del conocimiento de la situación que debían reunir los comisionados, la forma y modo de llevar a cabo su difícil misión es seguramente el elemento más importante a tener en cuenta; cuidar los gestos, las palabras, en definitiva, cuidar los detalles era fundamental, sobre todo para que los americanos entendiesen que no tenían nada que ver con las comisiones anteriormente enviadas ${ }^{24}$.

Por tanto, ya no se trata de una actitud de superioridad física; ya no se parte de una posición de poder fáctico, lo que obliga a adoptar una actitud prudente si se quiere llevar con éxito el objeto de la misión.

Dicho esto, no hay que olvidar que en el lenguaje que se emplea tanto en las instrucciones como en las prevenciones se deja entrever otro tipo de superioridad que tal vez sea parte de la causa del fracaso de esta negociación ab initio. Nos referimos a la superioridad moral. Los dirigentes españoles están convencidos de que la causa peninsular es justa ${ }^{25}$ frente a la disidente, y que en esta negociación parte de una superioridad moral respecto a lo que se considera

${ }^{23}$ Art. 19 Instrucciones, ídem nota 13.

${ }^{24}$ Art. 15 Instrucciones: «... es muy diverso el objeto de aquellas y de estas, teniendo ahora los gobiernos establecidos en América la mayor latitud para manifestar sus deseos y pretensiones, sin otra restricción que la indicada en el art. $1 .^{\circ}$ del decreto".

${ }^{25}$ Art. 14 Instrucciones: «... y habiendo tantos medios de defender las bases de justicia y de utilidad pública en que se funda nuestro actual sistema, debe aprovecharse esta ocasión para mostrar de palabra y por escrito los grandísimos beneficios que reportaría la América adoptando esta Constitución...»; Art. 22 Instrucciones en relación a la igualdad de derechos: «... con lo cual quedaría superabundantemente demostrada la injusticia, sin ningún fundamento semejante reconvención...»; Art. 2 Prevenciones: «... la evidente justicia y utilidad de los principios consagrados en la Constitución le ha grangeado mucho aprecio entre las personas ilustradas...». 
como "verdaderas intenciones de los americanos ${ }^{26}$, que subyace a lo largo de las «Prevenciones Reservadas a los Comisionados». El lapsus del término «metrópoli» a lo largo de estos documentos para referirse a la España peninsular da buena cuenta de ello ${ }^{27}$.

Se califica como «feliz» el sistema que rige en la Península (Instrucción 14) y, por ello, carece de sentido no abrazar la oferta de vivir en paz y armonía dentro del Estado Constitucional, que, en opinión de las autoridades peninsulares, es beneficioso para todos. Precisamente, esta confianza en el sistema, que solo por el hecho de existir parece que puede colmar y saciar las ansias emancipadoras, hace que se deposite en él todas las esperanzas de reconciliación.

La auctoritas española está presente en las instrucciones y prevenciones, ya que por parte del Ejecutivo peninsular se tiene menosprecio, no solo a la causa independentista americana, sino por la madurez y capacidad de desenvolverse en el panorama internacional en el caso de su emancipación; es decir, se sigue considerando a América como un territorio que para su supervivencia depende de España.

Su Majestad, al que se le cita en muchas ocasiones (arts. 9, 13, 16, 23, 29, 36; en las adicionales art. 5), se encuentra en la cúspide entre ambas partes. Tiene capacidad de resolver en caso de duda cualquier asunto que le sometan los comisionados, y ofrecer en su nombre olvido de lo sucedido a los jefes de los insurgentes ${ }^{28}$. No en vano, España seguía sin reconocer la existencia de esos nuevos Estados y, por tanto, el Jefe del Estado sigue siendo el Rey de España. Como muestra de ello, se había comunicado nota a los gabinetes extranjeros de la ofensa que supondría para España el reconocimiento por cualquier país de la existencia de dichos Estados ${ }^{29}$.

${ }^{26}$ Art. 4 Prevenciones: «... desengañados de que no se ha tratado ni trata de su bien y felicidad sino del interés de la facción que los dirige y que solo aspira a usurpar la autoridad y las riquezas...»; Art. 5 Prevenciones «... muchos a quienes sedujeron las primeras apariencias, se han desengañado después y han conocido que no fue el deseo del bien, sino el interés particular el que dirigió a los promotores de la insurrección...».

27 Ver art. 19 Instrucciones; art 6 Instrucción Adicional; arts. 1, 6 y 14 de las Prevenciones a los Comisionados.

${ }^{28}$ Art. 18 Instrucciones «... además del completo olvido de todo lo pasado, se les conservarán sus grados y sueldos y aun serán premiados en proporción de sus servicios y de lo que influyeron en el restablecimiento de la paz y de la unión...».

${ }_{29}$ DSC 13 febrero 1822, pág. 2298 Legislatura Extraordinaria 1821-1822, respecto al Voto particular de los diputados Moscoso y Toreno «Que el Gobierno español, por medio de una declaración á los demás con quienes está en relaciones amistosas, les manifieste que la Nación española mirará en cualquier época como una violación de los tratados el reconocimiento parcial ó absoluto de la independencia 
Debido a estas circunstancias, y a pesar del cambio de actitud frente al conflicto (el pacto en lugar de continuar la lucha armada), España sigue manteniendo una posición superior, si se quiere al menos solo en lo moral, en cuanto al comienzo de la negociación ${ }^{30}$. En definitiva, se trata de dar la imagen de que España encara de buena fe este proceso pacificador, en base al cual realiza concesiones, impensables pocos años antes, teniendo en cuenta que venía de una etapa absolutista. Pero, ¿se quiere hacer ver buena fe o en realidad es síntoma de impotencia por el devenir de los acontecimientos? Posiblemente una mezcla de ambas.

\section{II.2. Posición peninsular}

Como destaca Jensen, «la recuperación de la legalidad constitucional introdujo una nueva forma de encarar los conflictos existentes entre España y las provincias de Ultramar» ${ }^{31}$.

El cambio de actitud de España ante el conflicto americano permite entender lo mucho que estaba en juego, la supervivencia de España como potencia de primer orden en el panorama internacional.

No cabe duda que desde hacía tiempo, posiblemente con la derrota de Trafalgar en 1805, la existencia de España como imperio transoceánico tenía los días contados. No por ello hay que negar el mérito que España tuvo por domeñar esos vastos territorios, tal vez más en la teoría que en la práctica, durante casi 20 años después. A pesar de haber vencido al todopoderoso Napoleón, España era el centro de atención de muchas potencias europeas que veían, en la debilidad de ésta, una oportunidad inmejorable para ampliar sus dominios y abarcar más territorios a explotar por su industria cada vez más desarrollada ${ }^{32}$.

de las provincias españolas de Ultramar, entre tanto que no se hayan finalizado las disensiones que existen entre algunas de ellas y la Metrópoli, con todo lo demás que pueda convenir para acreditar á los Gobiernos extranjeros que la España no ha renunciado hasta ahora á ninguno de los derechos que le corresponden en aquellos países».

${ }^{30}$ Es preciso apuntar que mientras duraba la negociación podían suspenderse las hostilidades. Es importante esta aclaración, ya que no se trataba una obligación sino que, los comisionados, podían ponerse de acuerdo sobre este extremo con los jefes militares a favor de la causa española. Ver art. 8 Instrucciones y art. 4 Instrucción Adicional.

${ }^{31}$ Cfr. JENSEN, S.I., op. cit., págs. 51-98.

${ }^{32}$ La Revolución Industrial estaba en auge en las principales potencias europeas. No hay que olvidar que desde comienzos del siglo XIX comienza a gestarse los primeros movimientos obreros en España como el ludismo (consistía en romper máquinas). 
Comenzará la época del colonialismo del siglo XIX, la conquista de África, un continente inexplorado, si bien las costas habían servido de negreros para llevar esclavos a América. Gran parte del mundo hasta entonces conocido y explotado estaba dominado aún por España, por lo que las potencias europeas querían que se desquebrajase esta unidad territorial para llevar a cabo negocios y contratos comerciales con los nuevos estados americanos.

De esta forma, el contexto internacional no era el más propicio para encontrar apoyos por parte de los aliados europeos para aplacar el conflicto americano, a pesar de las peticiones de Fernando VII a la Santa Alianza ${ }^{33}$, y la propia Nación española se encontraba exhausta, en todos los aspectos, tras expulsar a las tropas del ejército más potente que había conocido Europa en siglos, La Grande Armée.

La negociación con los disidentes americanos terminó por ser aceptada por prácticamente todas las autoridades del nuevo, pero débil, Estado constitucional, si bien había límites que no se podían traspasar ${ }^{34}$.

De esta forma las instrucciones y prevenciones a los comisionados objeto de este trabajo, forman un conjunto de documentos necesarios para entender hasta qué punto España deseaba llegar a una conclusión del conflicto armado, así como la generosidad mostrada en sus condiciones, si se puede decir que había alguna, para lograr la pacificación, considerada beneficiosa para ambas partes.

$\mathrm{Y}$ es precisamente esa negociación con condiciones en donde surgía el conflicto, no solamente con los insurgentes o incluso con los diputados americanos en las Cortes, sino entre los propios diputados peninsulares. Una paz condicionada implica que se parte de una posición de poder que era inaceptable para los principales líderes de la insurgencia.

Además de la distinta posición política que se podía adoptar a la hora de llevar a cabo este tipo de negociaciones, lo que había era un gran desconocimiento por parte de los diputados y autoridades españolas del alcance del conflicto, como se observa en el Diario de Se-

33 VARELA SUANZES-CARPEGNA, J., op. cit. pág. 660.

${ }^{34}$ Art. 1 del Decreto Cortes 13 febrero 1822: «Que se nombren comisionados a propósito para presentarse a los diferentes gobiernos establecidos en las dos Américas españolas, oír y recibir todas las proposiciones que se les hicieren para transmitirlas a la metrópoli exceptuando aquellas que quitasen o limitasen de cualquiera modo a los españoles europeos y americanos la libertad de trasladas y disponer de sus personas, familias y propiedades como mejor les convenga», recogido por MIQUEL I VERGES, J.M., "La diplomacia española en México (1822-1823)», en Colegio de México, 1956, págs. 87-95. 
siones $^{35}$. Sin embargo, existían comunicaciones entre América y España, que se vieron muchas veces interrumpidas e interceptadas por los corsarios a las órdenes de los insurgentes, y ante la imposibilidad de disponer por parte de España de una fuerza armada que hiciera desaparecer esta situación, era muy difícil, por no decir imposible, que la comunicación fuera fluida y fiable ${ }^{36}$.

$\mathrm{Si}$ a eso se le añade que las personas que podían tener más conocimiento de la cuestión, como eran los diputados americanos, llevaban años fuera de sus lugares de origen y que además, en el seno de las discusiones parlamentarias daban a entender que toda América deseaba independizarse y no dejarse arrastrar por los hipotéticos beneficios constitucionales que el nuevo régimen constitucional les otorgaba, se puede concluir que España carecía del suficiente conocimiento como para negociar con fuerza su posición.

$\mathrm{Y}$ es que las autoridades peninsulares, después de negarse reiteradamente a negociar con los comisionados mandados a España por los disidentes, tuvieron que aceptar la tarea de enviar comisionados ultramarinos con una misión distinta a los anteriormente enviados, esto es, oír y recibir las proposiciones que les hicieran, para encontrar un punto beneficioso para ambas partes tras años de conflicto.

Estas instrucciones tratan de recoger los principales aspectos que desde las autoridades españolas se consideraban más importantes para negociar con los disidentes.

\section{INSTRUCCIONES Y PREVENCIONES}

A continuación, vamos a analizar los aspectos más relevantes tratados en las instrucciones y prevenciones otorgadas a los comisionados partiendo del contexto histórico y de unas reflexiones jurídicas previas en torno a la relación que ligaba a los comisionados con el mandato de las Cortes.

35 El diputado Navarrete aclara que la tardanza del Gobierno en tomar medidas sobre América no es por omisión dolosa sino por desconocimiento de América, DSC 15 de diciembre de 1821, n. ${ }^{\circ} 82$.; también ver intervención diputado Alamán sobre el desconocimiento del Gobierno de la situación en América al proponer medidas que son del Gobierno, otras que ya han sido acordadas por las Cortes y otras que considera que no son convenientes y otras que están comprendidas en el dictamen de la Comisión, DSC 27 de enero de 1822, pág. 2028, Legislatura Extraordinaria 18211822.

36 DSC 6 marzo 1821, Apéndice al núm. 9, lectura de la Memoria de Gil de la Cuadra. Ver art. 25 Instrucciones y art. 6 Instrucción Adicional en los que se hace mención a los corsarios. 


\section{III.1. Contexto de las instrucciones}

Las discusiones parlamentarias sobre el cometido de estos comisionados hace casi 200 años, así como que, según los exaltados, pudieran imponer su criterio sobre el Ejecutivo, da una idea de lo crucial que este asunto era para el devenir del nuevo Estado constitucional transoceánico.

América marca gran parte de los discursos del trienio, lo que hace destacar la importancia de la materia que estamos estudiando ${ }^{37}$. Ya desde el discurso inaugural del trienio liberal, de Fernando VII en las Cortes, el 9 de julio de $1820^{38}$, se aprecia de una manera evidente que América es el principal asunto de discusión. No hay que olvidar que el ejército destinado a América para aplacar el conflicto por la fuerza se subleva dando origen al trienio liberal.

Desde el artículo 1 de la Constitución de 1812, América está presente: «La Nación española es la reunión de todos los españoles de ambos hemisferios»; en esto se diferencia el constitucionalismo español frente a otras potencias, en donde no se trataba en pie de igualdad a los territorios que formaban parte de sus respectivos imperios.

El año en el que se dictan las instrucciones y prevenciones es 1822; desde febrero existía una mayoría de liberales exaltados en las Cortes que defendían que el Ejecutivo estaba supeditado al Legislativo $^{39}$. De esta forma las Cortes encomiendan al Gobierno que nombre comisionados para marchar a América con los poderes acordados en sede parlamentaria. Pero, no hay que olvidar, que a

37 En la contestación al discurso de la Corona de 9 Julio de 1820 «...El Congreso por su parte no omitirá ocasión de proponer y adoptar las disposiciones necesarias para la observancia de la Constitución y el restablecimiento de la tranquilidad en aquellas regiones, llegando así á formar la España de ambos mundos una sola y venturosa familia...»; otro ejemplo en el Discurso de apertura de las Cortes el 1 de marzo de 1821 «... Si el estado actual de la América no ha variado con relación a nosotros, la guerra por lo menos ha suspendido por ahora sus estragos y devastación en la Costa Firme; y el efecto que deben producir en aquellas regiones los notables acontecimientos de la Península, debe prometernos verlas de nuevo reunidas a la madre Patria como partes integrantes de un mismo imperio".

38 «... Tales son las que están pendientes con los Estados Unidos de América sobre el estado ulterior de las Dos Floridas y señalamiento de límites de la Luisiana. Existen también contestaciones ocasionadas por la ocupación de Montevideo y otras posesiones españolas en la orilla izquierda del Río de la Plata...»

39 Muy al contrario de lo que hasta ahora había sucedido, ya que tal y como se expuso por el Conde de Toreno las Cortes se eximían de la responsabilidad de tener que tomar decisiones respecto a la política de pacificación ultramarina, DSC 24 de junio de 1821, n. ${ }^{\circ} 117$, pág. 2448 Legislatura Ordinaria 1821. 
comienzos de 1822 el Gobierno es de la facción de los liberales moderados, cuya visión de la resolución del conflicto no era vista del mismo modo $^{40}$.

Por otra parte, el 25 de junio de 1822, la Comisión de Ultramar de las Cortes consideró ineficaz el envío de comisionados, según la resolución de 13 de febrero de 1822 . No será hasta agosto de 1822 cuando coincidan en las Cortes y en el Gobierno el grupo exaltado, lo que ocurrirá también cuando los comisionados partan hacia América en noviembre de 1822 (aunque algunos se encontraban ya allí) $)^{41}$.

Tampoco podemos pasar por alto las tensas relaciones entre, primero, el Rey y los diputados que en su mayoría eran de facción exaltada y, segundo, su propio Gobierno que, desde agosto de 1822 y hasta el final del trienio liberal, será exaltado ${ }^{42}$.

En medio de este contexto, se dictan las instrucciones con el cometido más importante que se hayan dado por las Cortes, esto es, la pacificación de América.

Esta búsqueda de soluciones al conflicto como si fuera un problema interno (a diferencia de lo expresamente pronunciado en los dictámenes del Consejo de Estado en $1821^{43}$ ) tiene como base que los exaltados no querían de ningún modo interferencia foránea del conflicto. No en vano, el régimen constitucional español no era visto con buenos ojos en una Europa marcada por el liberalismo doctrinario de la Santa Alianza ${ }^{44}$.

El hecho de que la pacificación de América se tratara en las Cortes como tema de política de Estado, que afecta a algo tan básico como es el ámbito del ejercicio de su poder, y las medidas políticas y jurídicas que se estaban llevando a cabo (indultos, igualdad territorial...), ya indica el hito histórico y jurídico que este debate supone.

40 Muchos incidían en sus intervenciones en que por el envío de comisionados no se presuponía la independencia de los territorios ultramarinos.

${ }^{41}$ Varios de los comisionados se encontraban allí, así para Tierra Firme y Nuevo Reino de Granada se confirmó el nombramiento de José Sartorio y J. Barry que desde 1820 estaban en Venezuela como comisionados. Véase FRIEDE, J., «España ante la Independencia», en Boletín Cultural y Bibliográfico, Vol. 10, n. ${ }^{\circ}$ 11, 1967, pág. 18 .

${ }^{42}$ VARELA SUANZES-CARPEGNA, J., op. cit., págs. 653-687.

${ }^{43}$ Destaca entre ellos el del 7 de noviembre de 1821.

44 VARELA SUANZES-CARPEGNA, J., op. cit., pág. 662. 


\section{III.2. Vinculación jurídica entre los comisionados y el Ejecutivo}

Debemos reflexionar sobre la siguiente cuestión: ¿Es incoherente que se emplee el término instrucciones y a la vez tengan un margen de actuación suficiente como para llevar la negociación a unos derroteros u otros en función de los avances que se vayan consiguiendo?

La capacidad de maniobra de la que disfrutaban los comisionados era bastante amplia a pesar de lo que el término «instrucciones» puede parecer. Son mandatarios con múltiples posibilidades de actuación, motivadas, sin duda por el mayor conocimiento del conflicto que debían tener y porque sólo «sobre el terreno» podía conocerse la mejor solución para llevarse a cabo. De esta forma, encorsetar su actuación a un estrecho margen no tenía sentido. Las Cortes y el Ejecutivo se encuentran a miles de kilómetros, y es in situ en donde se puede conocer con exactitud el alcance de la emancipación y las posibilidades de éxito de la misión.

Entonces, ¿se les mandaba a ciegas? No parece oportuno semejante planteamiento puesto que muchos americanos se encontraban en Madrid y, por tanto, se tenía cierta información de la situación. Aunque se reconoce incertidumbre en la respuesta de los disidentes a los comisionados ${ }^{45}$, no hay que olvidar que los propios diputados americanos en las Cortes en Madrid debatían y defendían sus opiniones basadas, en un primer momento, en la idea de adquirir amplias cotas de autonomía, hasta después terminar pidiendo y exigiendo la independencia ${ }^{46}$. Para corroborar más la afirmación de que «no van a ciegas», basta leer el artículo 2 de las prevenciones, en el que se hace referencia a que al Gobierno le consta el aprecio entre

${ }^{45}$ Como se aprecia en los arts. 10 y 19 de las Instrucciones, así como en art. 6 Instrucción Adicional.

${ }^{46}$ De la lectura del DSC, destaca en este aspecto la intervención del diputado mexicano Pablo la Llave «la diputación americana va a disolverse, y parte de la Península tal vez para siempre; pero parte con el consuelo de haber procurado constantemente, el bien de su madre; sí, de su madre, digan lo que quieran los enemigos de alegorías y metáforas: la diputación americana parte, pero parte con la gloria de haber cooperado á lo que tienen de más liberal las instituciones que rigen; parte con la esperanza de que vendrán á ocupar estos augustos asientos procuradores dignos de la Nación heróica; parte haciendo votos porque los peninsulares sean felices; parte con el proyecto de ir á preparar un asilo y días sabrosos á los hombres liberales y benéficos de todos los países; parte, en fin, con el presentimiento de que la América hará temblar algún día con su poder y virtudes á todos los déspotas y enemigos de sus hermanos de Europa...» (13 de febrero de 1822, pág. 2306. DSC Legislatura Extraordinaria 1821-1822). 
las clases ilustradas de los principios de justicia y utilidad consagrados en la Constitución ${ }^{47}$.

Planteadas las cosas en estos términos, al dejar el Ejecutivo esos márgenes de actuación a los comisionados, recae sobre sus hombros el buen éxito de la negociación ${ }^{48}$, si bien la resolución final se tomaría por las autoridades peninsulares ${ }^{49}$.

No hay que olvidar que el dictamen original de la Comisión de Ultramar fue revisado, limitando las facultades de los comisiona$\operatorname{dos}^{50}$, aunque manteniendo la discrecionalidad en su actuación, como se desprende de la literalidad de muchos de los artículos de las instrucciones y prevenciones.

Con el dictamen que finalmente se aprobó, se pasó del envío de comisionados con capacidad para tomar acuerdos, a un mandato más limitado, donde la posibilidad de encontrar puntos de encuentro con los disidentes estaba más alejado.

¿A qué figura jurídica actual se asemeja más esta encomienda, al mandato o a la mediación?

El contrato de mandato es definido por el artículo 1709 del Código civil, según el cual "por el contrato de mandato se obliga una persona a prestar algún servicio o hacer alguna cosa, por cuenta o encargo de otra». Se trata de un contrato consensual, que puede ser gratuito (unilateral) o retribuido (bilateral).

No consta en las instrucciones ni prevenciones que los comisionados cobren honorarios; no obstante, en carta de uno de los comisionados, Juan Barry, se dice que se le «deben haberes», por lo que se entiende que tenían algún tipo de compensación económica por los servicios realizados ${ }^{51}$.

47 Art. 2 Prevenciones: «...la evidente justicia y utilidad de los principios consagrados en la constitución le han grangeado mucho aprecio entre las personas ilustradas, como consta al gobierno...»

${ }^{48}$ Instrucción 31 «...se lamentaría mucho que siendo el gobierno español el que promueve la pacificación, se malograra por inadvertencia o indiscreción de los comisionados...»

49 Art. 29 Instrucciones, «Llegado el término de las conferencias y establecido ya el último resultado de las proposiciones, los comisionados las transmitirán sin dilación a Su Majestad por conducto de este ministerio, a fin de que desde luego pueda recaer sobre ellas la resolución que convenga»

50 DSC 12 de febrero de 1822, pág. 2273 DSC Legislatura Extraordinaria 1821/1822.

51 «...corro el riesgo de perecer de hambre y miseria, pues ningún socorro recibo de parte alguna. Pasa ya de cinco mil pesos fuertes los que se me debe...» Carta del Comisionado J. Barry el 5 de agosto de 1822, comisionado de Nueva Granada. AGI. Sevilla. IG. Legajo 1570, recogido por FRIEDE, J. «España y la Independencia», en Boletín Cultural y Bibliográfico, Vol. 11, n. ${ }^{\circ}$ 12, año 1968, pág. 120. 
Surge el problema de la distinción entre el mandato y la representación. En el caso de los comisionados parece que se asemeja más a la figura de la representación, aunque la decisión final se toma en las Cortes. Su misión consiste en oír y recibir las propuestas de las autoridades disidentes americanas, pero en muchas de las instrucciones se les indica la capacidad de negociar y concluir provisionalmente incluso pactos de comercio.

En este caso, debemos reconocer que al tener carácter plenipotenciario, los comisionados podían transigir acuerdos que desde ese momento producirían efectos, aunque fuera de forma provisional, siempre que no vayan en contra del decoro y dignidad de la Nación española ${ }^{52}$.

Respecto a la misión encomendada, es cierto que no se exige en el aspecto formal resultados, pero en las instrucciones se expresa, en concreto en la 31, que se lamentaría fracasar por la actitud de los comisionados. Además, parece que se cuida mucho de que los comisionados puedan aceptar dádivas y obsequios a nivel personal, por lo que parece que se intenta distinguir la relación personal de la misión que tienen encomendada ${ }^{53}$.

Con respecto a los efectos, al mandato no representativo se le aplica el artículo 1717 Cc: «cuando el mandatario obra en su propio nombre, el mandante no tiene acción contra las personas con quienes el mandatario ha contratado, ni éstas tampoco contra el mandante. En este caso el mandatario es el obligado directamente en favor de la persona con quien ha contratado, como si el asunto fuera personal suyo. Exceptuase el caso en que se trate de cosas propias del mandante». Al dar un amplio margen de actuación a los comisionados, parece que en el caso de fracasar, siempre se les podría achacar a ellos la culpa. Sin embargo, al existir límites en el mandato por los poderes explícitos que llevan consigo y que están autorizados por las Cortes, todo lo que traspasara dichos límites sería inválido o al menos no obligaría a la posición española.

52 Art. 5 Instrucción Adicional «... Su Majestad la concede expresamente a los comisionados para que, haciendo presentes a los gobiernos establecidos en América los perjuicios que son consiguientes a la interrupción de las negociaciones mercantiles entre uno y otro continente español, puedan transigir y estipular condicionalmente con dichos gobiernos unos pactos interinos de comercio que deben durar por lo menos tanto como las mismas comisiones, después de cuyo tiempo se resolverá con arreglo a las circunstancias; pero siempre de un modo ventajoso y útil para la península y la América...».

53 Art. 32 Instrucciones «...excusarán los comisionados cuanto sea dable, aunque sin afectación, la concurrencia a convites y a obsequios con que se quiera tal vez festejárseles...». 
Por su parte, al mandato representativo le es de aplicación lo dispuesto en el artículo $1725 \mathrm{Cc}$ : «El mandatario que obre en concepto de tal no es responsable personalmente a la parte con quien contrata sino cuando se obliga a ello expresamente o traspasa los límites del mandato sin darle conocimiento suficiente de sus poderes». Para este segundo supuesto, se establece una excepción en el segundo párrafo del artículo $1727 \mathrm{Cc}$ : «se permite que el exceso del mandatario sea ratificado por el mandante expresa o tácitamente». Esta figura del mandato representativo encaja con las instrucciones y prevenciones a los comisionados, ya que en lo que se excedan de su actuación, si es positivo para España, y no va contra el decoro y dignidad de la Nación, sería corroborado por las autoridades españolas.

Finalmente, en el caso que analizamos, el contrato se extinguió por no haberse podido ni siquiera iniciar formalmente la negociación.

En cuanto a la figura del contrato de mediación o corretaje, éste se puede definir como el contrato por el cual una persona se obliga a pagar a otra una remuneración o comisión por la información de la ocasión para concluir un contrato o por la mediación en un contrato. El corredor no obra ni como mandatario ni como representante del dominus, que concluirá efectivamente el negocio, pero como presta una actividad tendente a la conclusión de aquel contrato, al poner en relación a las dos partes, surge el derecho a esa remuneración o corretaje. Esta figura mediadora se asemeja mucho a la relación mantenida con los comisionados ultramarinos, ya que se pensaba que con la información que pudieran facilitar se podría llegar a concluir la tan ansiada pacificación. Si bien es verdad que, al disponer los comisionados de poderes expresos por parte de las autoridades españolas, parece que no encaja del todo esta figura jurídica.

El derecho del agente al cobro de sus honorarios ha de nacer desde el momento en que haya quedado perfeccionado el contrato cuya gestión se le había encomendado, a no ser que en el respectivo contrato de corretaje se haya estipulado expresamente que el corredor solamente cobrará cuando el contrato haya quedado consumado, mediante la cláusula salvo buen fin. Entre las obligaciones del mediador, salvo pacto expreso, no se encuentra la de garantizar la consumación del contrato. Parece que los honorarios de los comisionados, tal y como hemos comentado anteriormente, se cobran con independencia del éxito o fracaso, aunque es de suponer que si 
se conseguía la pacificación se tendrían en cuenta la gestión llevada a cabo y se recompensaría.

Por tanto, podríamos concluir que la actuación de los comisionados encaja con la figura jurídica del mandato con representación, ya que tienen poderes como receptores de la información que, de primera mano, les den las autoridades disidentes, si bien realizan igualmente funciones de mediación para tratar de acercar posturas y lograr la reconciliación.

\section{III.3. Principales contenidos}

Entre los contenidos a los que se refieren las instrucciones y prevenciones a los comisionados, se ha optado por destacar los que, a nuestro juicio, tienen una mayor relevancia a lo largo de su articulado, y que no hace más que evidenciar la trascendencia del cometido que tenían entre manos.

\section{II.3.1. Posiciones prudentes frente a intransigentes}

Es posible que desde la perspectiva actual de hoy no seamos capaces de comprender la trascendencia del acontecimiento que estamos estudiando, pero la encomienda a los comisionados es de tal relevancia como para poder afirmar que la posición de España en el panorama internacional podía variar drásticamente sino se lograban unos fructíferos resultados de esta negociación. Actualmente, sabemos su resultado: la separación definitiva del continente americano; pero entonces no estaba claro y por ello la actitud, el lenguaje y la persuasión eran armas que cobraban mucha más importancia que cualquier ejército que la exhausta España pudiera enviar.

Si se hace un análisis en profundidad tanto de las instrucciones como de las prevenciones, se puede apreciar las innumerables muestras de prudencia que deben adoptar los comisionados ante las hipotéticas situaciones a las que se podían enfrentar, y respuestas que debían dar en el devenir de la negociación. España quería llevar este asunto tan delicado con extrema cautela; no arriesgar demasiado en una jugada que podía llevar al traste la verdadera partida de ajedrez en la que se encontraba el conflicto. También en las instrucciones y prevenciones hay ejemplos de posiciones enérgicas que forman, lo que nos atrevemos a denominar «líneas rojas», es decir, principios y

(C) UNED. Revista de Derecho UNED, núm. 23, 2018 
postulados que no se pueden traspasar sin herir el decoro y honor de la Nación Española ${ }^{54}$.

\section{III.3.2. Referencia a la Constitución española y a las Cortes}

Como hemos indicado en páginas anteriores, el art. 15 de las instrucciones destaca que no se trata de una continuación de la comisión enviada por España en $1820^{55}$ principalmente por dos motivos: la vigencia de un régimen constitucional y la existencia de unas Cortes capaces de frenar los múltiples excesos de la época absolutista anterior. El Rey ya no dirige la negociación entre las dos partes que constituyen la familia española en el mundo, sino las Cortes. Esta premisa es fundamental para que los americanos entiendan que ya no están frente a una Metrópoli que les trata como a niños, sino frente a sus hermanos españoles peninsulares. Pasan de ser colonias a ser provincias, de tener derechos por voluntad del Rey y la Metrópoli a tenerlos reconocidas en la Constitución, cúspide del sistema jurídico del incipiente Estado constitucional transoceánico.

Son múltiples las expresiones que justifican los beneficios que la Constitución otorga a la nueva etapa que se encuentra ante sus ojos.

\section{III.3.3. Unidad frente a separación}

Como indicamos en páginas anteriores, se transmite en las instrucciones y prevenciones, al igual que en muchas intervenciones de los diputados en las Cortes ${ }^{56}$, una fe ciega en que la unidad

${ }^{54}$ Un estudio completo sobre el concepto Nación puede encontrarse en VARELA SUANZES-CARPEGNA, J., La teoría del Estado en los orígenes del constitucionalismo hispánico. Centro de Estudios Constitucionales. Madrid. 1983. Citado por SÁNCHEZ AGESTA, L., "Sobre los orígenes del constitucionalismo hispánico», en Revista de Derecho Constitucional, n. ${ }^{\circ} 11$, Año 4, mayo-agosto, 1984, págs. 243-249.

55 «... Mientras tenían lugar estos contactos en Londres, el gobierno español había decidido enviar comisionados a Venezuela y Buenos Aires cuya misión no consistía tanto en negociar alguna concesión concreta a los insurgentes como en informar a los gobiernos republicanos del nuevo talante constitucional de la monarquía y sus deseos de poner fin cuanto antes a una guerra fratricida...» DELGADO RIVAS, J.M. «La desintegración del Imperio Español, un caso de descolonización frustrada (1797-1837)», en Illes i Imperis: Estudios de historia de las sociedades en el mundo colonial y post-colonial, N. ${ }^{\text {a }} 8,2006$, págs. 5-44

56 «La Nación no puede en estos críticos momentos abandonar ni dejar de su mano a las provincias que todavía le pertenecen de derecho, sean cuales fuesen los designios y sentimientos: esta autoridad es útil a la América misma para preservarla de mil males que desconoce y a que se halla expuesta por la ambición y la codicia, ya no de simples particulares... sino de Estados poderosos». DSC 25 de junio 1822, 
es la única manera de evitar que América sea desplazada y devorada por potencias extranjeras que solo ven en ella un mercado en el que abastecerse para seguir su desarrollo a costa del sufrimiento de aquellos habitantes.

Gracias a mantener esa unidad y abrazar la Constitución se pueden llegar a olvidar los excesos de la guerra así como perdonar a los disidentes ${ }^{57}$, que van en la línea de actuación de la política conciliadora con que se encaró desde el principio este conflicto durante el trienio liberal ${ }^{58}$. Llama la atención que se fundamente la independencia de América dentro de la unidad del nuevo Estado constitucional transoceánico ${ }^{59}$. En apariencia es una antítesis que, desde la postura española, es viable al entender la independencia como no dependencia de la Península en la toma de múltiples decisiones. De esta forma, la Constitución garantiza una cierta autonomía como parte integrante que son de la Monarquía española ${ }^{60}$.

Este punto es crucial ya que, gracias a la unidad, España podía mantenerse en el panorama político internacional como potencia de primer orden, y así evitar lo que tanto por sus propias torpezas,

n. ${ }^{\circ} 158$, pág. 2158 DSC Legislatura Ordinaria 1822. Se puede retrotraer a sesión 8 de septiembre 1820, pág. 892 Legislatura Ordinaria 1820 «... los americanos estaban íntimamente convencidos de que existiendo ésta todas las promesas serían religiosamente cumplidas, guardando sus derechos y de tal manera protegidos, que los esfuerzos de la arbitrariedad y el despotismo, cuando osase alguno hacerlos, serán severamente reprimidos y castigados...».

57 Art. 18 Prevenciones «... desde luego les ofrezcan en nombre del rey, que, además del completo olvido de todo lo pasado, se les conservarán sus grados y sueldos y aun serán premiados en proporción de sus servicios y de lo que influyeron en el restablecimiento de la paz y de la unión...».

58 Real Orden de 31 de marzo de 1829; ver también sesión 11 de julio de 1820, n. ${ }^{\circ} 7$, pág. 32 DSC Legislatura Ordinaria 1820 en la que el diputado por Buenos Aires Francisco Magariños propuso que se concediese una amnistía general para toda la España Ultramarina, aprobándose finalmente el Decreto de Amnistía General para América el 27 de septiembre de 1820. Cfr. JENSEN, S.I., op. cit. págs. 51-98

59 Ibid, destaca la autora que en 1821 los diputados liberales afirmaban que desde el restablecimiento de la Constitución, la independencia estaba sancionada porque tanto las provincias americanas como la Península eran partes integrantes de la Monarquía y con idénticos derechos y obligaciones (26 de octubre de 1821, n. ${ }^{\circ}$ 32, págs. 393-394 DSC Legislatura Extraordinaria 1821/1822).

60 Antes de la existencia de la Constitución de Cádiz, la Junta Suprema Central, el 22 de enero de 1809, declaró que las colonias españolas de América «no son propiamente colonias o factorías, como las de otras naciones, sino una parte esencial e independiente de la Monarquía española»; Misma declaración en el Art. 19 Instrucciones «... proporciona y asegura a la América la independencia más cumplida, puesto que declarada parte integrante de la monarquía e igual en derechos a todas las demás partes de esta, no dependen todos sino de las leyes que hacen los representantes que ellas mismas eligen, siendo por consiguiente la España americana tan independiente como la europea...». 
como por el interés de los que se consideraban sus aliados, propiciaron su aislamiento internacional y la pérdida del protagonismo político que en los últimos siglos, con más o menos éxito, tenía España.

\section{CONCLUSIONES}

Las Cortes españolas, con el objeto de mantener un Estado uniforme bajo una misma Constitución, intentó restablecer las relaciones de ambas Españas, europea y ultramarina, truncada por años de conflicto. Para ello, se encomendó a un órgano externo a las Cortes, en concreto al Ejecutivo, que mandase unos comisionados para tratar de lograr el éxito que ni la Constitución, ni las discusiones en el seno de las Cortes, ni anteriores comisionados, ni siquiera el ejército español, habían conseguido asegurar.

Es evidente que fracasaron en su cometido puesto que no pudieron evitar que América se separara de la incipiente España constitucional, pero no es menos cierto que las dificultades que encontraron fueron de tal envergadura que incluso hoy, casi doscientos años después, sigue pareciendo una misión en la que, debido a diversos factores - la distancia, la dificultad de las comunicaciones, la inestabilidad política y la fragilidad del nuevo Estado constitucionalresultó imposible contrarrestar una situación irreversible desde el punto de vista político.

La nueva posición jurídica que ocupaba América en el nuevo régimen constitucional no era suficiente para apaciguar los ánimos de los disidentes americanos, para los que la libertad e independencia de España serían suficientes para hacer frente a todos los males que podían avecinarse ${ }^{61}$. La independencia terminó convirtiéndose en un fin en sí mismo, que había que conseguir fuera como fuese, con o sin el reconocimiento de España.

La inestabilidad política de la época en la Península y el contexto internacional fueron elementos clave para la separación americana, por lo que poco podían hacer los comisionados. Además, a excepción de los que se encontraban ya en tierras americanas en el momento de expedirse estas instrucciones y prevenciones, no pudieron ni siquiera llegar a sus destinos y tratar de conseguir lo que, a todas

${ }^{61}$ En relación con esta cuestión, invitamos al lector a consultar la magnífica obra de FERNÁNDEZ RODRÍGUEZ, T.R., La Constitución de 1812. Utopía y realidad, Dykinson, Madrid, 2011. 
luces, parecía más una esperanza, una ilusión, que una realidad concreta sobre la que trabajar en la negociación.

Si bien es cierto que entre los americanos no había uniformidad en cuanto a la idea de la independencia, no puede negarse que el contexto histórico invitaba a adoptar la emancipación a las nuevas naciones ultramarinas que basaron sus anhelos separatistas en los principios que precisamente informaban el nuevo constitucionalismo hispánico.

No deja de ser, cuanto menos curioso, que precisamente cuando los americanos alcanzan cotas de autonomía, libertad e incluso identidad en pie de igualdad dentro del Estado constitucional transoceánico, se produzca la separación definitiva del continente.

Tal vez, el momento en el que las Cortes autorizaron al Ejecutivo a enviar a estos comisionados, con un mandato distinto a los anteriores, era un momento muy tardío; pero no es menos cierto que los trámites burocráticos y los vaivenes políticos, con mayorías moderadas o exaltadas tanto en las Cortes como en el Ejecutivo que chocaban, sobre todo estas últimas, con el Monarca obligado por las circunstancias, a abrazar los principios constitucionales-, no permitió que pudiera consolidarse en América una Constitución que, estaba, «...formada tanto para la prosperidad de ellas como de la península....» tal y como indican las instrucciones en su artículo 14.

Pero igual que decimos que no se consolidó el sistema constitucional gaditano en América, tampoco se consiguió en España, ya que Fernando VII fue instalado de nuevo como monarca absoluto en 1823, estableciendo, por el Decreto de 26 de enero de 1824, la revocación de cualquier medida que hubieran podido hacer los comisionados enviados a América «que sean contrarios a los legítimos derechos de la Corona de España y a mi real soberanía».

Lo que sucedió fue lamentable para ambas partes. Esta situación produjo un cambio drástico para la posición española y americana en el panorama internacional. España dejó de ser parte activa en el mismo, pasando a ser una potencia de segundo orden al albur de los intereses de las principales potencias europeas. Por su parte, los nuevos estados americanos adoptaron como propios los principios de la Constitución de Cádiz, aunque no pudieron evitar una etapa de conflictos internos (entre clases sociales y raciales) y externos (respecto a las fronteras de los nuevos Estados) que lastraron su porvenir y que, aún hoy día, en muchos de ellos se sigue apreciando. 
Poco podía esperarse de un sistema que ni siquiera se afianzaba en su lugar de origen, la Península, pero a la que contribuyeron en su confección notables diputados americanos y que otorgó a los territorios ultramarinos un reconocimiento como nunca antes habían tenido.

No podemos dejar de recordar el valor e importancia del que puede considerarse último intento que el constitucionalismo español utilizó para cohesionar un Estado que estaba herido de muerte por enemigos tanto internos - facciones absolutistas-, como externos - las potencias europeas veían en los mercados americanos la posibilidad de dar salida a su incipiente industria-.

En definitiva, con este breve estudio hemos pretendido recordar ese intento de pacificación que, aunque fracasó, debe ser objeto de profunda admiración como el último esfuerzo de un régimen constitucional que revolucionó el mundo jurídico contemporáneo europeo, al poner en pie de igualdad las antiguas colonias, ahora provincias, con la Metrópoli europea, y que trató de consolidar unos principios que, tanto por los hombres que tuvieron que ponerlos en práctica como por el contexto histórico en el que se dieron, propiciaron el triste desenlace que todos conocemos.

A modo de recapitulación, y a la vista de lo expuesto, invitamos una vez más a reflexionar en torno a las diferencias y similitudes entre aquel régimen constitucional de hace 200 años y la España actual, regida por el Estado democrático y de Derecho, como ya hiciera, de una forma soberbia, el recientemente fallecido José Manuel Pérez-Prendes ${ }^{62}$.

\section{FUENTES Y BIBLIOGRAFÍA}

\section{A. Fuentes}

Diarios de Sesiones de Cortes del trienio liberal, 1820-1823.

Instrucciones para los comisionados destinados a las provincias de Ultramar en consecuencia de lo dispuesto por el Decreto de las Cortes Extraordinarias de 13 de febrero de este año. Archivo General de Indias, Sevilla, Indiferente General legajo 1570.

${ }^{62}$ Cfr. PÉREZ-PRENDES, J.M., "¿Es un círculo el camino?» en El Cronista del Estado Social y Democrático de Derecho, n. ${ }^{\circ} 31$, octubre, 2012, Iustel, págs. 18-24. 
Instrucción Adicional aprobada por el rey para los comisionados destinados a las provincias de Ultramar. Archivo General de Indias, Sevilla, Indiferente General legajo 1570.

Prevenciones reservadas a los comisionados nombrados por S.M. para las provincias disidentes de Ultramar. Archivo General de Indias, Sevilla, Indiferente General legajo 1570.

Comisión Política de la Nueva Granada. Reservado. Duplicado. Archivo General de Indias, Sevilla, Indiferente General legajo 1570.

\section{B. Bibliografía}

Chust, M., «La notoria trascendencia del constitucionalismo doceañista en las Américas», Corts: Anuario de derecho parlamentario, n. ${ }^{\circ}$ 26, 2012, págs. 47-58.

Delgado Rivas, J.M., «La desintegración del Imperio Español, un caso de descolonización frustrada (1797-1837)», en Illes i Imperis: Estudios de historia de las sociedades en el mundo colonial y postcolonial, n. ${ }^{\circ} 8,2006$, págs. 5-44.

FERnÁNDEZ RodríGUez, T.R., La Constitución de 1812. Utopía y realidad, Dykinson, Madrid, 2011.

FRIEDE, J., «España ante la Independencia» Boletín Cultural y Bibliográfico, vol. 9, núm. 5, 1966, págs. 849-852; vol. 10, n. ${ }^{\circ} 11,1967$, págs. 18-40; vol. 11 n. ${ }^{\circ} 12$, 1968, págs. 89-122.

GIL Novales, A., El Trienio Liberal, Madrid, Siglo XXI, 1980.

JENSEN, S.I., «El problema americano en el Trienio Liberal. Análisis de las Políticas de Ultramar de las Cortes Españolas (1820-1823)», en Trienio, n. ${ }^{\circ} 28$, nov. 1996, págs. 51-98.

LYNCH, J., Las revoluciones hispanoamericanas, 1808-1826, Barcelona, Ariel, 1983.

Miquel i Verges, J.M., «La diplomacia española en México (18221823)», en Colegio de México, 1956.

Pascual, P., La unión con España, exigencias de los diputados americanos en las Cortes de Cádiz, Comunidad de Madrid, 2001.

Peña González, J., Historia política del constitucionalismo español, Dykinson, Madrid, 2006.

PÉREZ-Prendes, J.M., “¿Es un círculo el camino?» en El Cronista del Estado Social y Democrático de Derecho, n. ${ }^{\circ} 31$, octubre, 2012, Iustel, págs. 18-24. 
SÁnChez Agesta, L., «Sobre los orígenes del constitucionalismo hispánico», en Revista de Derecho Constitucional, n. ${ }^{\circ} 11$, Año 4, mayoagosto, 1984, págs. 243-249.

SÁnChEz ANDRÉs, A., "La búsqueda de un nuevo modelo de relaciones con los territorios de Ultramar durante el Trienio Liberal (1820-1823)», en Revista de Indias, 1997, vol. LVI, núm. 210, págs. 451-474.

Torres Del Moral, A., "1812: La apuesta constitucional de Cádiz», Servicio de publicaciones Universidad de Cádiz, Cádiz, 2014,

Varela Suanzes-Carpegna, J., «La Monarquía imposible: la Constitución de Cádiz durante el Trienio", en Anuario de Historia del Derecho Español, t. LXVI (1996), págs. 653-687.

La teoría del Estado en los orígenes del constitucionalismo hispánico. Centro de Estudios Constitucionales. Madrid. 1983. 